\title{
PERFORMA PERTUMBUHAN HIBRIDA ANTARA IKAN KERAPU BATIK BETINA (Epinephelus microdon) DENGAN IKAN KERAPU KERTANG JANTAN (E. lanceolatus) YANG DIPELIHARA PADA SALINITAS BERBEDA
}

\section{GROWTH PERFOMANCE OF HYBRID BETWEEN FEMALE CAMOUFLAGE GROUPER (Epinephelus microdon) WITH MALE GIANT GROUPER (E. lanceolatus) CULTURED IN DIFFERENT LEVEL OF SALINITY}

\author{
Ahmad Fahrul Syarif ${ }^{1 *}$, Dinar Tri Seolistyowati ${ }^{2}$ dan Harton Arfah ${ }^{2}$ \\ ${ }^{1} J u r u s a n$ Akuakultur, Fakultas Pertanian Perikanan dan Biologi, \\ Universitas Bangka Belitung \\ Kampus Terpadu UBB, Gedung Teladan, Desa Balunijuk, Bangka, \\ Kepulauan Bangka Belitung, 33172 Indonesia \\ ${ }^{2}$ Departemen Budidaya Perairan, Institut Pertanian Bogor \\ Jl. Raya Dramaga, Babakan, Bogor, Jawa Barat 16680 Indonesia \\ Email: ahmadfahrulsyrif@gmail.com
}

\begin{abstract}
ABSTRAK
Hibridisasi antara spesies ikan kerapu batik (Epinephelus microdon) betina dan ikan kerapu kertang (E. lanceolatus) jantan terus dikembangkan untuk memperoleh strain baru dengan performa unggul. Penelitian ini bertujuan untuk mengevaluasi performa pertumbuhan hibrida ikan kerapu "TIKTANG" (hibridisasi antara ikan kerapu batik betina x ikan kerapu kertang jantan) terhadap perbedaan salinitas 10, 20 dan 30 ppt pada beberapa parameter pertumbuhan panjang dan bobot. Percobaan dirancang menggunakan Rancangan Acak Lengkap (RAL) dengan tiga perlakuan perbedaan salinitas dan masingmasing diulang sebanyak tiga kali. Pemeliharaan dilakukan selama 21 hari dengan metode pemberian pakan secara at satiation. Hasil penelitian menunjukkan bahwa derajat kelangsungan hidup ikan kerapu hibrid "TIKTANG" selama pemeliharaan sebesar $100 \%$, sedangkan performa pertumbuhan baik panjang maupun bobot menunjukan perlakuan 10 ppt lebih rendah dibandingkan 20 dan 30 ppt $(p<0,05)$.
\end{abstract}

Kata kunci : Hibridisasi, Epinephelus microdon, E. lanceolatus, Performa Pertumbuhan, Salinitas, TIKTANG

\section{ABSTRACT}

Hybridization between female camouflage grouper Epinephelus microdon and male giant grouper Epinphelus lanceolatus has been developed to obtain new strain with superior performance. This research aimed to evaluate growth performance of hybrid fish called "TIKTANG" (the hybridization between female camouflage grouper $x$ male giant grouper) with different salinity levels 10, 20 dan 30 ppt in some parameters of length and weight. The cultured experiments was designed using a completely randomized design (CRD) in three level of salinity and each treatments repeated three times. Cultured was conducted in 21 days with feeding method is at satiation. The result showed that the survival rate of hybrid fish "TIKTANG" is $100 \%$, thus the growth performance of length and showed that treatment of the 10 ppt had lower performance than 20 ppt and 30 ppt $(p<0,05)$.

Keywords : Hybridization, Epinephelus microdon, E. lanceolatus, Grwoth Performance, Salinity, TIKTANG

\section{PENDAHULUAN}

Ikan Kerapu Epinephelus sp. umumnya dikenal dengan istilah "groupers" merupakan salah satu komoditas perikanan yang mempunyai peluang baik di pasar domestik maupun pasar internasional karena nilai jualnya yang cukup tinggi. Beberapa jenis ikan Kerapu Epinephelus sp. telah mulai diujicoba pembesarannya di Indonesia, Malaysia, Singapura, Thailand dan Hongkong sejak tahun 1979 (Sugama et al., 1986). Menurut data statistik kelautan dan 
perikanan, produksi ikan kerapu di Indonesia meningkat sebesar 9,52\% pertahun selama 5 tahun terakhir. Sehingga usaha budidaya ikan kerapu merupakan andalan dalam peningkatan produksi komoditas marikultur Indonesia.

Peningkatan produksi ikan kerapu perlu di dukung dengan ketersediaan benih yang berkualitas secara kontinyu. Mutu benih ditentukan dari kualitas induk melalui seleksi dan perkawinan (selective breeding) yang terkontrol (Moav dan Wohlfarth, 1976). Strategi breeding dapat dilakukan untuk populasi induk pada spesies yang sejenis, maupun berbeda spesies atau strain melalui crossbreeding (hibridisasi). Dalam selective breeding metode yang digunakan disesuaikan dengan tujuannya yaitu mengeksploitasi keunggulan sifat tetua serta upaya dalam menggabungkan sifat tetua dalam populasi keturunanya sehingga diperoleh performa yang lebih unggul.

Menurut Tave (1993) dan Dunham (1995), seleksi individu dan seleksi famili efektif dilakukan untuk mengarahkan dominasi sifat-sifat unggul yang diinginkan jika heritabilitasnya sedang sampai tinggi. Sebaliknya, apabila kemiripan individu dalam populasi tinggi atau keragaman fenotipnya rendah maka target sifat yang dikehendaki dapat diperoleh dengan seleksi famili dan introduksi ragam genetik melalui hibridisasi.

Penelitian tentang program hibridisasi telah dilakukan di Indonesia antara lain; hibridisasi empat strain ikan mas Rajadanu, Majalaya, Kuningan dan Subang (Ath-Thar et al., 2011). Hibridisasi antara ikan mas (Cyprinus carpio) dengan ikan nilem (Osteochilus hasselti) (Syamsiah, 2001) dan hibridisasi antara Oreochromis aureus dan Oreochromis niloticus. Manfaat hibridisasi adalah memperbaiki kualitas benih seperti perbaikan laju pertumbuhan, penundaan kematangan gonad pada produksi monoseks agar tercapai pertumbuhan yang maksimal seperti pada ikan nila, meningkatkan ketahanan terhadap penyakit dan lingkungan yang kurang baik, menghasilkan strain hibrid dengan keunggulan heterosis (hybrid vigour) pada individu hetrosigot (Gustiano, 1991). Hibridisasi pada ikan dapat dibedakan menjadi 3 macam yaitu; hibridisasi intraspesifik (spesies sama), hibridisasi interspesifik (antar spesies yang berbeda) dan hibridisasi intergenerik (antar genus yang berbeda) (Hickling, 1968).

Jenis ikan kerapu yang dihasilkan melaui program hibridisasi telah mulai dikembangkan oleh Balai Budidaya Air Payau
Situbondo yaitu ikan kerapu hibrid cantang. Ikan kerapu ini merupakan hasil hibridisasi antara ikan kerapu macan (Epinephelus fuscoguttatus) betina dengan ikan kerapu kertang (Epinephelus lanceolatus) jantan dengan keunggulan hibrid yaitu pertumbuhan yang relatif lebih cepat dibandingkan ikan kerapu macan dan resisten terhadap penyakit seperti VNN. Sifat pertumbuhan yang relatif cepat diduga diturunkan oleh ikan kerapu kertang.

Program hibridisasi ikan kerapu pada awalnya dimulai pada tahun 1983 oleh peneliti asal Cina dan Hongkong (Tseng dan Poon, 1983) yang berhasil melakukan hibridisasi antara Epinephelus akaara dengan E.amplychephalus. Hasil hibrida tersebut memiliki keunggulan yaitu pertumbuhan larva yang jauh lebih tinggi dibandingkan kedua tetuanya. Beberapa peneliti lain juga berhasil melakukan hibridisasi antara Epinephelus costae dengan E. marginatus (Glamuzina et al., 2001), hibridisasi antara Plectropomus leopardus dengan Plectropomus maculatus (Frisch dan Hobbs, 2007) dan hibridisasi antara Epinephelus coioides dengan Epinephelus lanceolatus (Kiriyakit et al., 2011).

Beberapa jenis ikan kerapu yang potensial untuk dikembangkan melalui hibridisasi, misalnya ikan kerapu batik Epinephelus microdon dan ikan kerapu kertang Epinephelus lanceolatus. Ikan kerapu batik memiliki keunggulan toleransi terhadap perubahan salinitas dan kekeruhan yang tinggi, namun kelemahan ikan ini adalah tingkat pertumbuhan yang rendah dan rentan terhadap penyakit. Ikan kerapu kertang memiliki keunggulan yaitu, tingkat pertumbuhan yang tinggi dan resisten terhadap penyakit. Benih ikan kerapu dari hasil persilangan tersebut diharapkan memiliki sifat unggul dari kedua tetuanya yaitu toleran terhadap perubahan salinitas dan laju pertumbuhan yang tinggi. Benih hasil hibrid ini diharapkan dapat dijadikan kandidat ikan yang bisa dipelihara pada tambak-tambak bersalinitas rendah. Sehingga pada penelitian dilakukan untuk menguji dan mengevaluasi performa pertumbuhan ikan kerapu hibrid "TIKTANG" (hibridisasi antara ikan kerapu batik betina $\mathrm{x}$ ikan kerapu kertang jantan) pada salinitas yang berbeda.

\section{METODE PENELITIAN}

Ikan kerapu hibrid "TIKTANG" merupakan, ikan hasil hibridisasi antara ikan 
kerapu batik betina dengan ikan kerapu kertang jantan melalui pemijahan secara buatan. Perangsangan pematangan gonad induk dilakukan secara hormonal yaitu menggunakan hormon HCG dengan dosis $1000 \mathrm{IU} / \mathrm{kg}$ dan Ovaprim dengan dosis 0,5 $\mathrm{ml} / \mathrm{kg}$. Setelah kedua induk matang gonad maka dilakukan proses stripping untuk mengeluarkan sperma dan telur. Ketika telur dan sperma telah dikeluarkan maka keduanya dicampurkan pada sebuah wadah berupa plastik misalnya baskom agar terjadi pembuahan (fertilisasi). Telur yang telah dibuahi kemudian ditetaskan pada bak penetasan dan pemeliharaan dengan dimensi $2 \times 5 \times 1,25 \mathrm{~m}$. Pemeliharaan larva ikan kerapu hibrid "TIKTANG" hingga berumur \pm 60 hari sesuai dengan SPO (Standar Prosedur Operasional) yang diterapkan BBAP Situbondo, Jawa Timur.

\section{Prosedur Uji Performa Pertumbuhan Terhadap Perbedaan Salinitas}

Uji performa pertumbuhan terhadap salinitas dilakukan untuk mengetahui fenotipe ikan hasil hibrid "Tiktang" terhadap perbedaan salinitas (10, 20 dan 30 ppt) karena ikan kerapu pada umumnya hidup pada lingungan air laut dengan kisaran 30-34 ppt. Ikan kerapu "TIKTANG" yang digunakan berumur \pm 60 hari dengan bobot rata-rata $2,68 \pm 0,09$ gram dan panjang rata-rata $5,46 \pm 0,15 \mathrm{~cm}$ berjumlah 300 ekor.

\section{Aklimasi Benih Ikan}

Benih ikan kerapu hibrid "TIKTANG" di aklimasi dengan penurunan 2 ppt perhari secara bertahap hingga mencapai salinitas yang diujikan. Penurunan pada benih perlakuan 30 ppt dilakukan selama 1 hari, benih perlakuan 20 ppt dilakukan selama 6 hari dan benih perlakuan 10 ppt dilakukan selama 11 hari.

\section{Persiapan Wadah Pemeliharaan}

Wadah perlakuan yang digunakan berupa bak plastik berdimensi $60 \times 40 \times 40 \mathrm{~cm}$ berjumlah 15 buah dengan volume air yang diisi sebanyak 60 liter. Wadah perlakuan dilengkapi dengan instalasi aerasi berupa selang dan batu aerasi yang dihubungkan dengan pipa PVC berdiameter 1 inchi pada blower utama. Pembuatan media dengan perbedaan salinitas dilakukan dengan metode pengenceran media bersalinitas berkisar antara 33-35 ppt dengan air tawar 0 ppt melalui rumus persamaan $\left(V_{1} \times M_{1}=V_{2} \times M_{2}\right)$, sehingga diperoleh ketiga salinitas perlakuan yang diharapkan. Selanjutnya, masing- masing wadah diisi dengan air sesuai perlakuan salinitas yang telah ditentukan yaitu $10,20,30$ ppt dan ikan ditebar.

\section{Metode Pemberian Pakan}

Pakan ikan kerapu hibrid "TIKTANG" selama pemeliharaan 21 hari berupa pelet komersial benih ikan kerapu yang diberikan setiap 2 jam sekali mulai pukul $07.00 \mathrm{~s} / \mathrm{d}$ 17.00 WIB dengan metode pemberian pakan secara at satiation atau sekenyangnya.

\section{Suplai dan Pengelolaan Kualitas Air}

Kebutuhan air laut di BBAP Situbondo diambil dari laut sejauh 250-300 m dari garis pantai yang dialirkan melalui pipa PVC dengan diameter pipa 8 inchi menggunakan pompa berkekuatan 21 PK. Sebelum digunakan, air laut disaring dengan menggunakan filter fisik di dalam bak filter dengan konstruksi beton. Air laut yang sudah masuk pada tandon perlakuan berkapasitas 1000 liter kemudian di teratment menggunakan chlorin dengan dosis 5-10 ppm kemudian diaerasi kencang selama 24 jam kemudian dinetralkan dengan $\mathrm{Na}$-Tiosulfat $1 / 2$ dari dosis pemberian chlorin. Setelah minimal 3 jam, maka air siap digunakan. Pengelolaan kualitas air dilakukan setiap hari dengan metode pergantian air sebanyak $70 \%$ dari volume awal. Frekuensi pergantian air adalah 2 kali sehari pada jam 07.00 dan 15.00 bersamaan dengan itu dilakukan pula penyifonan dasar bak.

\section{Parameter Penelitian}

Derajat kelangsungan hidup dihitung dengan menggunakan rumus Effendie (1997), yaitu :

Derajat Kelangusngan Hidup $=\frac{N t}{N o} \times 100 \%$

Keterangan : $\mathrm{Nt}=$ Jumlah Ikan Di Akhir Pemeliharaan; No $=$ Jumlah Ikan Awal Pemeliharaan

Laju pertumbuhan harian dihitung dengan menggunakan rumus Huisman (1987), yaitu :

$$
\alpha=\left[t \sqrt{\frac{\overline{\mathrm{W}} \mathrm{t}}{\overline{\mathrm{W}} 0}}-1\right] \mathrm{X} 100 \%
$$

Keterangan: $\alpha=$ Laju pertumbuhan harian (\%); $\overline{\mathrm{Wt}}=$ Bobot rata-rata ikan pada waktu $\mathrm{t}(\mathrm{g}) ; \overline{\mathrm{Wo}}=$ Bobot rata-rata ikan pada awal percobaan $(\mathrm{g}) ; \mathrm{t}=$ Lama percobaan (hari) 
Pertumbuhan bobot harian dihitung dengan menggunakan rumus Effendie (1997), yaitu :

$$
\text { Pertumbuhan Bobot Harian }=\frac{\bar{W} t-\bar{W} 0}{t}
$$

Keterangan : $\overline{\mathrm{Wt}}=$ Bobot rata-rata ikan pada waktu $\mathrm{t}(\mathrm{g}) ; \overline{\mathrm{Wo}}=$ Bobot rata-rata ikan pada awal percobaan $(\mathrm{g}) ; \mathrm{t}=$ Lama percobaan (hari)

Pertumbuhan panjang mutlak dihitung dengan menggunakan rumus Effendie (1997), yaitu :

Pertumbuhan Panjang Mutlak $=\overline{\mathrm{L}} \mathrm{t}-\overline{\mathrm{L}} 0$

Keterangan: $\overline{\mathrm{Lt}}=$ Panjang rata-rata ikan pada waktu $\mathrm{t}(\mathrm{cm}) ; \overline{\mathrm{LO}}=$ Panjang rata-rata ikan pada awal percobaan $(\mathrm{cm})$

Alat dan metode pengukuran beberapa parameter kualitas air yang dilakukan tertera (Tabel 1).

Tabel 1. Alat dan Metode Pengukuran Parameter Kualitas Air

\begin{tabular}{ccc}
\hline Parameter & Alat & Metode \\
\hline $\mathrm{pH}$ & $\mathrm{pH}$ Meter & Insitu \\
Ammoniak & Phenat & Spektrofotometri \\
Suhu & Termometer & Insitu \\
DO & DO Meter & Insitu \\
\hline
\end{tabular}

\section{Analisis Data}

Data performa pertumbuhan meliputi Derajat Kelangsungan Hidup (DKH), Laju Pertumbuhan Harian (LPH), Pertumbuhan Bobot Harian (PBH) dan Pertumbuhan Panjang Mutlak (PPM) dianalisis menggunakan Microsoft Excel 2010 dan SPSS 17.0 (ANOVA) pada selang kepercayaan 95\%. Data Kualitas air dibahas dan dianalisis secara deskriptif.

\section{HASIL DAN PEMBAHASAN}

Derajat kelangsungan hidup ikan kerapu hibrid "TIKTANG" selama pemeliharaan 21 hari pada perlakuan dengan salinitas 10 ppt, 20 ppt dan 30 ppt mencapai $100 \%$. Derajat kelangsungan hidup yang tinggi dipengaruhi oleh kemampuan beradaptasi pada lingkungan pemeliharaan. Menurut Soewardi (2007), strategi adaptasi suatu populasi terhadap lingkungannya dipengaruhi oleh faktor genetik yaitu keragaman genetik selain keunggulan masing-masing tetua yang diwariskan pada hibrida yang salah satunya adalah kemampuan adaptasi terhadap salinitas rendah.
Laju pertumbuhan harian ikan kerapu hibrid "TIKTANG" yang dipelihara pada salinitas $10 \mathrm{ppt}, 20 \mathrm{ppt}, 30 \mathrm{ppt}$ berkisar antara $7,64 \pm 0,050 \%$ sampai dengan $8,34 \pm 0,030 \%$ (Gambar 1), dimana rata-rata laju pertumbuhan harian pada perlakuan 10 ppt adalah paling rendah yaitu sebesar $7,64 \pm 0,050 \%$. Berdasarkan uji statistik yang telah dilakukan dapat diketahui bahwa perlakuan 10 ppt menunjukan perbedaan laju pertumbuhan harian dibandingkan perlakuan 20 ppt dan 30 ppt $(P<0,05)$. Sedangkan pada perlakuan 20 ppt dan 30 ppt tidak ada perbedaan laju pertumbuhan harian $(P>0,05)$.

Pertumbuhan bobot harian ikan kerapu hibrid "Tiktang" yang dipelihara pada salinitas 10 ppt, 20 ppt, 30 ppt adalah berkisar antara $0,224 \pm 0,020$ gram/hari sampai dengan 0,256 $\pm 0,010$ gram/hari (Gambar 2) dengan nilai rata-rata pertumbuhan bobot harian terendah adalah 0,224 $\pm 0,020$ gram/hari yaitu pada perlakuan $10 \mathrm{ppt}$. Berdasarkan uji statistik yang telah dilakukan dapat diketahui bahwa perlakuan 10 ppt menunjukan perbedaan pertumbuhan bobot harian dibandingkan perlakuan $20 \mathrm{ppt}$ dan $30 \mathrm{ppt}$ $(P<0,05)$. Sedangkan pada perlakuan $20 \mathrm{ppt}$ dan 30 ppt tidak ada perbedaan pertumbuhan bobot harian $(P>0,05)$.

Pertumbuhan panjang mutlak ikan kerapu hibrid "TIKTANG" yang dipelihara pada salinitas $10 \mathrm{ppt}, 20 \mathrm{ppt}, 30 \mathrm{ppt}$ adalah berkisar antara $1,823 \pm 0,258 \mathrm{~cm}$ sampai dengan 2,247 $\pm 0,206 \mathrm{~cm}$ (Gambar 3) dengan nilai rata-rata pertumbuhan panjang mutlak terendah adalah $1,823 \pm 0,258 \mathrm{~cm}$ yaitu perlakuan 10 ppt. Berdasarkan uji statistik yang telah dilakukan dapat diketahui bahwa perlakuan 10 ppt menunjukan perbedaan pertumbuhan panjang mutlak dibandingkan perlakuan 20 ppt dan 30 ppt $(P<0,05)$.

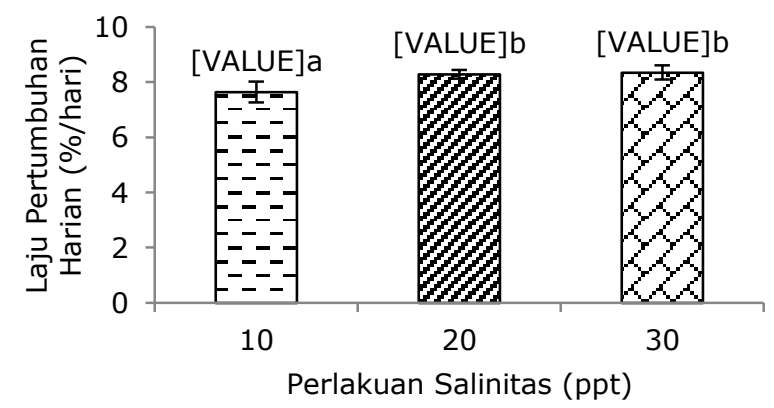

Keterangan : Huruf superscript yang berbeda menunjukkan pengaruh yang berbeda nyata $(P<0,05)$

Gambar 1. Laju pertumbuhan harian ikan kerapu hibrid "TIKTANG" pada perlakuan salinitas 10, 20, 30 ppt. 


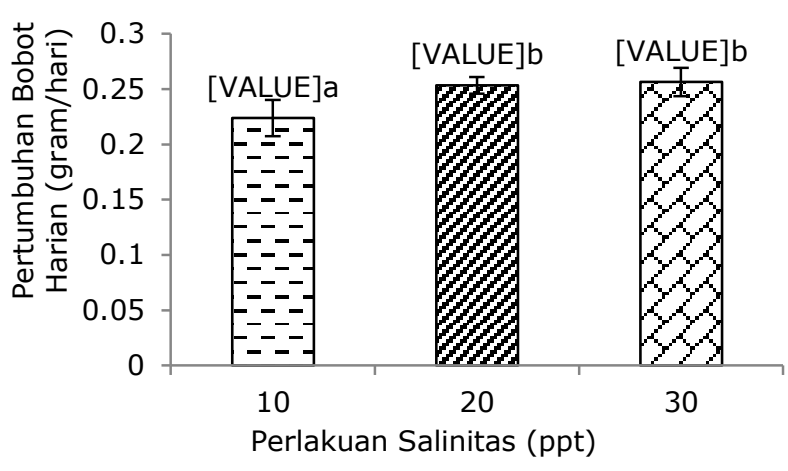

Keterangan : Huruf superscript yang berbeda menunjukkan pengaruh yang berbeda nyata $(P<0,05)$

Gambar 2. Pertumbuhan bobot harian ikan kerapu hibrid "TIKTANG" pada perlakuan salinitas $10,20,30$ ppt.

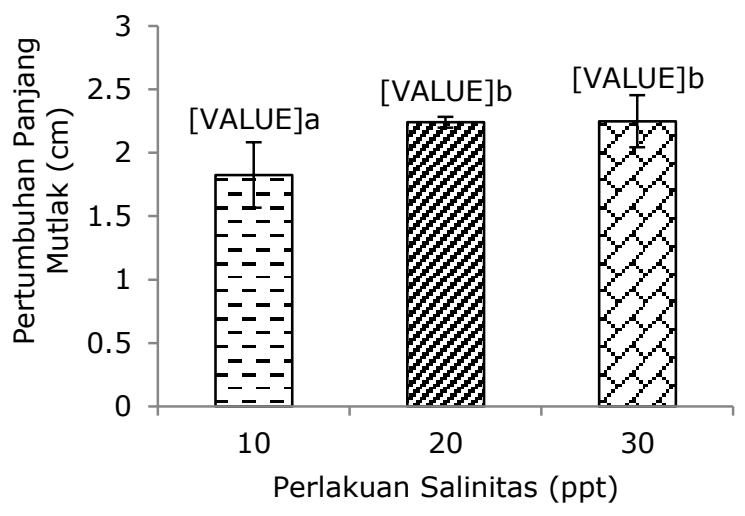

Keterangan : Huruf superscript yang berbeda menunjukkan pengaruh yang berbeda nyata $(P<0,05)$

Gambar 3. Pertumbuhan panjang mutlak ikan kerapu hibrid "TIKTANG" pada perlakuan salinitas $10,20,30$ ppt.

Sedangkan pada perlakuan 20 ppt dan 30 ppt tidak ada perbedaan pertumbuhan panjang mutlak $(P>0,05)$.

Kemampuan beradaptasi terhadap salinitas pada ikan kerapu hibrid "TIKTANG" menunjukkan peranan genetis hibrid dan pembiasaan (adapted). Menurut Soewardi (2007) kondisi ini pada umumnya terjadi akibat proses adaptasi yang terus menerus terhadap kondisi lokal dan memungkinkan populasi mengaktifkan gen-gen yang diperlukan. Salinitas mempengaruhi strategi beradaptasi terutama osmoregulasi dan respon fisiologis lainnya yaitu metabolisme yang berdampak pada pertumbuhan bobot dan panjang ikan kerapu hibrid "TIKTANG". Di alam ikan kerapu umumnya hidup pada kisaran salintas 30-33 ppt dan kemampuan ikan untuk bertahan perbedaan salinitas tergantung aktifitas pengaturan cairan tubuh untuk mempertahankan tingkat tekanan osmotik yang mendekati normal. Peningkatan atau penurunan salinitas dapat mempengaruhi laju metabolisme yaitu memicu pergerakan pernapasan, tingkat konsumsi oksigen yang tinggi dan ekskresi yang tinggi pada ikan (Taqwa, 2008). Pemborosan energi yang terjadi pada ikan kerapu hibrid "TIKTANG" terkait metabolisme dan ekskresi yang tinggi diduga mempengaruhi rendahnya pertumbuhan pada perlakuan salinitas 10 ppt. Nilai ammonia yang cukup tinggi pada perlakuan $10 \mathrm{ppt}$ pada masa pemeliharaan yaitu sebesar $0.14 \pm 0.1 \mathrm{mg} / \mathrm{l}$ juga merupakan stressor selain penurunan salinitas yang cukup tinggi pada kasus ini.

Berdasarkan hasil pengukuran kualitas air (Tabel 2) menunjukan bahwa tingkat stress pada ikan kerapu hibrid "TIKTANG" pada saat pemeliharaan sangat tinggi khususnya pada perlakuan 10 ppt yang terlihat dari parameter amoniak yang tinggi melampaui batas minimum yang seharusnya. Sedangkan parameter kualitas air yang lain menunjukan kisaran normal yang sesuai dengan Standart Biological Requirment (SBR) pemeliharaan ikan kerapu.

Menurut Tave (1994), variasi fenotipe $\left(V_{P}\right)$ merupakan penjumlahan dari 3 komponen yaitu variasi genetik $\left(V_{G}\right)$, variasi lingkungan $\left(V_{E}\right)$ dan interaksi antara variasi genetik dan lingkungan $\left(\mathrm{V}_{\mathrm{G}-\mathrm{E}}\right)$. Variasi genetik dipengaruhi oleh materi genetik individual diantaranya status genotipe heterosigot lebih menguntungkan terkait dengan potential fitness dan tingkat heritabilitas yang berasal dari kontribusi gen aditif. Komponen $V_{P}$ tanpa dasar genetik adalah keragaman $V_{E}$, dalam hubungannya dengan variabel yang nyata dan berkaitan dengan pertumbuhan, sedangkan keterkaitan genetik dan fenotipe dapat diketahui dengan melihat hubungan DNA dan RNA. Kemampuan ikan kerapu hibrid "TIKTANG" dalam merespon salinitas dengan pertumbuhan yang optimal hanya mencapai 20 ppt, seharusnya ikan hibrida ini dapat merespon hingga salinitas $10 \mathrm{ppt}$ dengan pertumbuhan yang stabil dengan pembiasaan. Varians interaksi tersebut timbul karena beberapa alel bertanggung jawab terhadap suatu fenotipe yang diekspersikan secara berkala dalam lingkungan yang berbeda (Fujaya, 1999), sehingga diduga aktivasi gen yang diturunkan dari kedua induk (ikan kerapu batik dan ikan kerapu kertang) pada lingkungan mempengaruhi ekspresi fenotipe ikan kerapu hibrid "TIKTANG" dan mengarah pada stabilitas performa hibrid pada salinitas rendah. 
Tabel 2. Data Kualitas Air Selama Pemeliharaan

\begin{tabular}{ccccc}
\hline Perlakuan & $\mathrm{pH}$ & Amoniak $(\mathrm{mg} / \mathrm{l})$ & Suhu $\left({ }^{\circ} \mathrm{C}\right)$ & $\mathrm{DO}(\mathrm{ppm})$ \\
\hline $10 \mathrm{ppt}$ & $8.35 \pm 0.13$ & $0.14 \pm 0.1$ & $26.01 \pm 1.23$ & $7.58 \pm 0.20$ \\
$20 \mathrm{ppt}$ & $8.12 \pm 0.17$ & $0.09 \pm 0.01$ & $25.76 \pm 0.96$ & $7.52 \pm 0.16$ \\
$30 \mathrm{ppt}$ & $7.99 \pm 0.16$ & $0.05 \pm 0.02$ & $26.06 \pm 1.12$ & $7.44 \pm 0.26$ \\
Pustaka & \multirow{2}{*}{$6.5-9(\mathrm{KKP}, 2011)$} & $<0.01(\mathrm{KKP}$, & $24-31($ Chua dan & $>3,5($ Chua dan \\
Rujukan & & $2011)$ & Teng, 1978) & Teng, 1978) \\
\hline
\end{tabular}

\section{KESIMPULAN}

Hibridisasi antara ikan kerapu batik betina dan ikan kerapu kertang jantan menghasilkan ikan kerapu hibrid "TIKTANG" dengan kemampuan merespon salinitas hingga 20 ppt dengan kelangsungan hidup mencapai $100 \%$ dan pertumbuhan bobot harian rata-rata 0,25 gram/hari. Ikan kerapu hibrid "TIKTANG" potensial dikembangkan sebagai kandidat ikan kerapu yang dapat dipelihara di tambak bersalinitas antara 2030 ppt.

\section{REFERENSI}

Ath-Thar, M.H.F., Prakoso, V.A. dan Gustiano, R. 2011. Keragaan Pertumbuhan hibridisasi empat strain ikan mas. Berita Biologi 10(05): 2011

Dunham, R.A. 1995 . The contribution of genetically improved aquatic organism to global food security international conference on suistenable contribution of fisheries to food security. Japan: $\mathrm{KC} / \mathrm{f} 1 /$ Tech/6 FAO $111 \mathrm{pp}$.

Effendie, M.I. 1997. Biologi perikanan. Yogyakarta (ID): Yayasan Pustaka Nusantara.

Frisch, A.J. and Hobbs, J.P.A. 2007. In vitro hybridization of coral trouts, Plectropomus leopardus (Lacepede, 1802) and Plectropomus maculatus (Bloch, 1790): a preliminary investigation. Aquaculture Research 38:251-218.

Fujaya. 1999. Dasar-dasar Genetika dan Pengembangbiakan Ikan. Makassar (ID)

Glamuzina, B., Glavic, N., Skaramuca, B., Kozul, V. and Tutman, P. 2001. Early development of the hybrid Epinephelus costae female $x$ E. marginatus male. Aquaculture. 198(1):55-61.

Gustiano, R. 1991. Hibridisasi antar genus:sebagai terobosan dalam penyediaan bibit unggul. Warta Penelitian dan Pengembangan Pertanian 13:7-8. DOI: $10.1016 / \mathrm{S} 0044-8486(00)$ 00511-1
Hickling, C. 1986. Fish hybridization proc of world symposium on warm water pond fish culture. FAO Fish Rep 44:1-10.

Huisman, E.A. 1987. The principles of fish culture production. Netherland: Departement of Aquaculture, Wageningen University.

Kiriyakit, A., Gallardo, W.G. and Bart, A.N. 2011. Succesful hybridization of grouper (Ephinephelus coidodes $\mathrm{x}$ Epinephelus lanceolatus) using cryopreserved sperm. Aquaculture 320:106-112.

Moav, R. and Wohlfarth, G.W. 1976. Two way selection for growth rate in the common carp (Cyprinus carpio L.). Genetics. 82:83-101.

Soewardi, K. 2007. Pengelolaan Keragaman Genetik Sumberdaya Perikanan Dan Kelautan. Bogor (ID): Institut Pertanian Bogor.

Sugama, K., Waspada dan Tanaka, H. 1986. Perbandingan laju pertumbuhan beberapa jenis kerapu, Epinephelus spp. dalam kurung-kurung apung. Scientific Report of Mariculture Research and Development Project (ATA-192) in Indonesia: 211-219.

Syamsiah,H. 2001. Karakteristik morfometrik dan meristik benih ikan hibrida antara ikan mas (Cyprinus carpio L.) betina dan ikan nilem (Osteochilus hasselti C.V.) jantan [Skripsi]. Bogor (ID): Institut Pertanian Bogor.

Taqwa, F.U. 2008. Pengaruh penambahan kalium pada masa adaptasi penurunan salinitas dan waktu penggantian pakan alami oleh pakan buatan terhadap performa pascalarva udang vaname (Litopenaeus vannamei ). [Tesis]. Bogor (ID): Institut Pertanian Bogor.

Tave, D. 1993. Genetics For fish managers. USA: AVI Publ.Comp.Inc 1994. Selective Breeding Programes For Medium-Sized Fish Farm. Rome : FAO Fisheries Technical Paper 122p.

Tseng WY, Poon CT. 1983. Hybridization of epinephelus species. Aquaculture 34:177-182. 